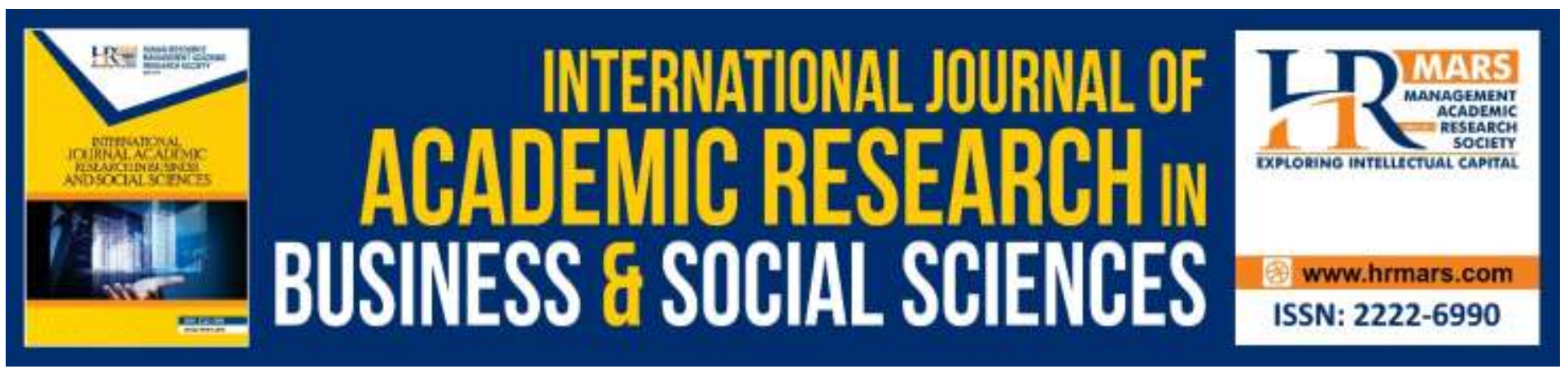

\title{
The Impact of Patriarchy on Women's Political Participation
}

\section{Hamoon Khelghat-Doost, Suzyrman Sibly}

To Link this Article: http://dx.doi.org/10.6007/IJARBSS/v10-i3/7058

DOI:10.6007/IJARBSS/v10-i3/7058

Received: 03 February 2020, Revised: 22 February 2020, Accepted: 14 March 2020

Published Online: 31 March 2020

In-Text Citation: (Khelghat-Doost \& Sibly, 2020)

To Cite this Article: Khelghat-Doost, H., \& Sibly, S. (2020). The Impact of Patriarchy on Women's Political Participation. International Journal of Academic Research in Business and Social Sciences, 10(3), 396-409.

Copyright: (C) 2020 The Author(s)

Published by Human Resource Management Academic Research Society (www.hrmars.com)

This article is published under the Creative Commons Attribution (CC BY 4.0) license. Anyone may reproduce, distribute, translate and create derivative works of this article (for both commercial and non-commercial purposes), subject to full attribution to the original publication and authors. The full terms of this license may be seen

at: http://creativecommons.org/licences/by/4.0/legalcode

Vol. 10, No. 3, 2020, Pg. 396 - 409

http://hrmars.com/index.php/pages/detail/IJARBSS

JOURNAL HOMEPAGE

Full Terms \& Conditions of access and use can be found at http://hrmars.com/index.php/pages/detail/publication-ethics 


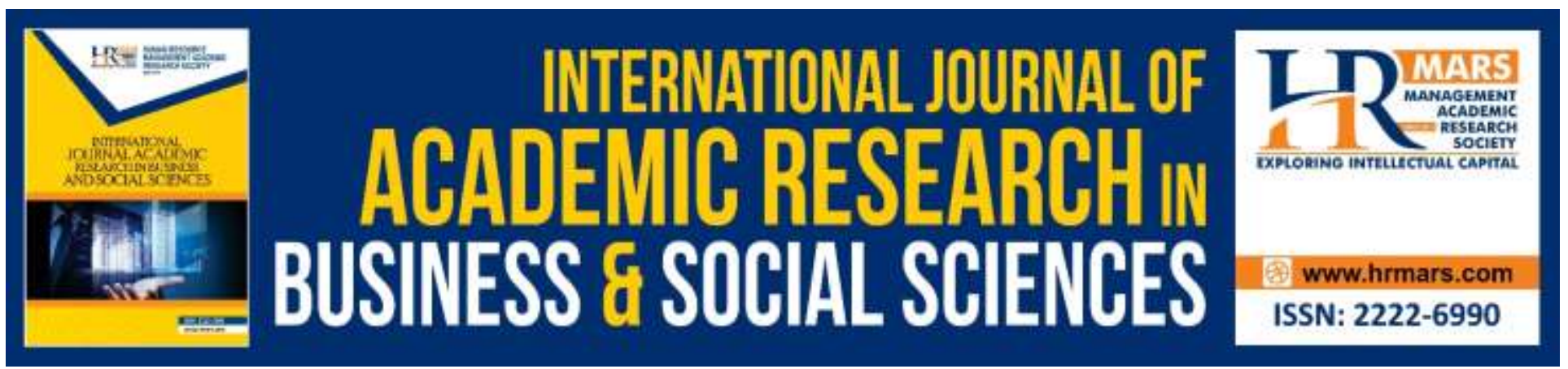

\title{
The Impact of Patriarchy on Women's Political Participation
}

\author{
Dr. Hamoon Khelghat-Doost, Dr. Suzyrman Sibly \\ Centre for Global Sustainability Studies (CGSS), Universiti Sains Malaysia (USM) \\ Email: hamoon@usm.my, suzyrman@usm.my
}

\begin{abstract}
Patriarchy advocates a domesticized set of roles for women. These roles have been achieved through developing the dichotomous discourse of public (for men) and private (for women) spheres in which women should be restricted to household. By the end of the $20^{\text {th }}$ century and with the rapid expansion of globalization and worldwide movements towards democracy, women's efforts to challenge the dominant patriarchal system through more active participation in political decisionmaking process in different levels increased accordingly. Although as a global trend, women's participation in politics is increasing, however, the quality and quantity of such increasing trend vary in different societies. By using secondary literature, this paper seeks to explain why despite facing very limited legal obstacles against participation in different levels of political processes, women's political roles and participation are generally less significant than their male counterparts. To answer this question, this paper develops three structural categories, by which patriarchy obstructs women's participation in politics in practice.
\end{abstract}

Keywords: Women, Patriarchy, Political Participation, Gender

\section{Introduction}

There are several diverse notions along which the world is divided into different categories including gender, race, religion, nations, class or political ideologies. Gender relations and the position of women in society have been always a topic of serious discussions among scholars in different academic fields. As "the most basic and prevalent category in social life throughout the world" (Epstein, 2007; 2), gender and women's position in gender discourse also play an important role in global politics which "has traditionally been a male domain that many women have found unwelcoming or even hostile" (United Nations, 2005). In most countries of the world, women face very limited legal obstacles against their participation in different levels of political processes yet in compare with their male counterparts, women's political roles and participation are generally less significant. 
Understanding the gender divides, it is also important to recognize that women's position in global gender discourse is not static but dynamic. In examining women's relative position, it is also important to consider the ever-changing unstable temporal and spatial global conditions especially in terms of culture, politics and economics. These changes are functions of different variables such as culture, social context, technological advancements, state-market relations, education and framing (Gerson and Peiss, 1985; Johnston, et al. 1995).

By the end of the $20^{\text {th }}$ century and with the rapid expansion of globalization and worldwide movements towards democracy, women's efforts for more active participation in political decisionmaking process in different levels increased accordingly. Although as a global trend, women's participation in politics is increasing, however, the quality and quantity of such increasing trend vary in different societies.

In several countries, special regulations are placed to maximize women's political roles and participations. Affirmative actions are among these initiatives. In these societies (such as Afghanistan, Argentina, Egypt, South Korea or France) a quota system is introduced to ensure a certain minimum degree of participation of women in political decision-making processes such as in occupying parliamentary or ministerial seats. Some political parties in countries such as Sweden, Israel, Australia or Germany have also assigned a certain number of positions reserved for women to ensure a more gender balanced representation.

In line with the above background and by using secondary literature, this paper seeks to explain why despite facing very limited legal obstacles against participation in different levels of political processes, women's political roles and participation are generally less significant than their male counterparts.

To provide the answer for this question and by reviewing the current literature on women's political participation; this paper first identifies patriarchy as the main reason for women's less significant global political roles and participation in compare with their male counterparts. Next this paper develops three structural categories by which patriarchy obstructs women's political participation in practice. Identifying these structural categories in this paper will assist scholars with having a holistic view on who patriarchy works in practice to hamper women's access to politics.

\section{Review of Literature}

Patriarchy and its definition have been one of the most debated topics in studying gender relations in different disciplines. The existence of various definitions for patriarchy has been also one of the sources for such debates. The word patriarchy is originated from the Greek word patriarkhēs which can be literally translated as "the rule of the father" (Green, 2010; 969). Originally, the concept of patriarchy was referring to the rule of any elder male over other younger members of the family regardless of their gender. This has been the basis for Weber's approach towards patriarchy as a special form of household in which "the father dominated other members of an extended kinship network and controlled the economic production of the household" (Barrett, 1980; 10).

However, in recent time, the definition of patriarchy in the context of gender relations is mostly narrowed down by feminist scholars to the dominating role of men in subordinating women. Narrowing down patriarchy in such a way is mostly viewed as feminists desire to search "for an explanation of feelings of oppression and subordination and in the desire to transform feelings of rebellion into a political practice and theory" (Beechey, 1979; 66). 
INTERNATIONAL JOURNAL OF ACADEMIC RESEARCH IN BUSINESS AND SOCIAL SCIENCES Vol. 10, No. 3, March, 2020, E-ISSN: 2222-6990 @ 2020 HRMARS

Patriarchy is core to several different theories in studying gender relationships and feminism namely "radical feminist, Marxist feminist and dual systems theory" (Pilcher and Whelehan, 2004; 93). Scholars such as Cynthia Fuchs Epstein are among those belonging to the radical feminist camp in which social divisions based on sex are considered as the "root issue" in "the organizational basis of most major institutions, including the division of labor in the home, the workforce, politics, and religion" (Epstein, 2007; 1).

The same approach towards viewing sex as the main source of women's subordination to men is emphasized by other feminist scholars such as Millett (1977), "there remains one ancient and universal scheme for the domination of one birth group by another -the scheme that prevails in the area of sex." Relating sex and biology to the exploitative role of men in patriarchy, Firestone (1979) attacks the imbalanced power structure of "the biological family" and introduces the "natural reproductive difference between the sexes" as the origin of the discriminative division of labor and caste systems. Along with this argument, Rich (1980) takes a further step to question the "natural origins' of heterosexuality and argues that the concept of "biological reproductive capacity" is only a socio-political construct which is "founded on male interest and prerogative" (p. 32) to further establish male supremacy and subordinate women's position in a patriarchal system.

As an alternative to view patriarchy from the biological functioning point of view, Marxist feminism "analyzes the relationship between the subordination of women and the organization of various modes of production" (Beechey, 1979; 66). Both Marx and Engels introduced the "division of labor in the sexual act" as the origins of the current global structure of the labor division (Marx and Engels, $1970,51)$ and therefore concluded that the current gender inequality is a byproduct of capitalism. However, note should be taken that there is a wide range of theories and approaches within Marxist feminism in dealing with patriarchy.

A group of Marxist feminist scholars such as Juliet Mitchell in Psychoanalysis and Feminism (1974) explain patriarchy as an ideology. Through this approach, she rejects the radical feminist's emphasis on biology as the main driver of patriarchy and turns to Levi-Strauss' (1969) argument of kinship systems in which exchange relations are explained as the backbone of societies, and "the exchange of women by men is a fundamental form of exchange which accounts for the particular social position in which women are placed in all human societies" (Beechey, 1979; 72). To explain the reasons for women becoming the objects of exchange, she turns to the Freudian psychoanalysis approach and argues that Oedipus complex is the main factor to understand how "patriarchal ideology perpetuates itself through the institution of the family-as-mediator between nature (biology) and culture (social rules and roles)" (Hunter, 2007; 18).

Against the two mentioned approaches towards patriarchy, the third approach 'duel system' came into existence as the output of criticizing the radical and Marxist feminisms for over emphasizing on biology and class. Hartmann (1979) argues that patriarchy was already existed before capitalism comes into the picture. With the emerge of capitalism, the already existing patriarchal structure was expanded by the capitalist structure through its agents (male workers) and various mechanisms such as job segregation by sex and creating domestic division of labor. She therefore, believes in interdependency between patriarchy and capitalism and argues that patriarchy "shapes the form modern capitalism takes, just as the development of capitalism has transformed patriarchal institutions" (Hartmann, 1979; 208). 
Patriarchy therefore can be broadly defined as "a kinship-ordered social structure with strictly defined sex roles in which women are subordinated to men" (Moghadam, 1992). However, the emphasis on the biological aspects of the concept through kinship is criticized by scholars such as Sylvia Walby. She dismisses the biological elements in explaining patriarchy and therefore defines it as "a system of social structures and practices in which men dominate, oppress and exploit women" (Walby, 1989; 20). Defining patriarchy in this way also prevents us from overgeneralizing the malefemale relations as naturally exploitative in favor of men.

In her book, Theorizing Patriarchy, Walby (1989) puts forward six structures which shape patriarchy namely; "the patriarchal mode of production, patriarchal relations in paid work, patriarchal relations in the state, male violence, patriarchal relations in sex, and patriarchal relations in cultural institutions" (p. 20). Simultaneously, Walby argues that the nature of patriarchy has evolved throughout time from a private matter to a public affair. In traditional forms of patriarchy (private), women's subordination was explained through its exploitation in the household level whereas the evolved form of patriarchy (public) is revolving around women's oppression in public spheres such as work places or the state.

This review of literature reveals that patriarchy by nature is the main obstacle to women's participation in politics. However, what lacks in the current literature is a proper categorization of how and in which capacities does patriarchy hinder women's political participation. This paper therefore puts forward a set of categories by which patriarchy obstructs the path of women's political participation in practice.

\section{Women and Political Participation}

Women's participation in different levels of political activities is generally low throughout the world. Based on the 2019 statistics published by the UN Woman (United Nations Entity for Gender Equality and the Empowerment of Women), only $24.3 \%$ of the national parliament seats throughout the world are occupied by women. At the same time, there are 38 states in which less than $10 \%$ of their parliament members are women. The percentage of female members of parliament also varies significantly in different regions of the world. This include "Nordic countries, 42.5\%; Americas, 30.7\%; Europe excluding Nordic countries, 27.4\%; sub-Saharan Africa, 23.7\%; Asia, 19.6\%; Pacific, 18.4\%; and the Middle East and North Africa, 18.1" (UN Report on Women in Politics, 2019).

In analyzing women's membership in parliament, it is important to notice that out of the 39 parliaments with more than 30\% female members, 32 use a form of quota system for women's participation (UN Report on Women in Politics, 2019). The quota system ultimately aims to "recruit women into political positions and to ensure that women are not only a few tokens in political life" (Dahlerup, 2005). These quota systems include "Reserved seats (constitutional and/or legislative), Legal candidate quotas (constitutional and/or legislative) or Political party quotas (voluntary)" (Quota Project, 2009). In general, only one in five parliamentarians is female.

Women are also extremely marginalized in occupying state leadership roles. According to UN Report on Women in Politics (2019), as June 2019, only 11 women hold the position as the Head of State 
INTERNATIONAL JOURNAL OF ACADEMIC RESEARCH IN BUSINESS AND SOCIAL SCIENCES Vol. 10, No. 3, March, 2020, E-ISSN: 2222-6990 @ 2020 HRMARS

$(11 / 152=7.2 \%)$ while 12 others serve as the Head of Government $(12 / 193=6.2 \%) .{ }^{1}$ Women in ministerial positions are also lagging behind their male counterparts. In terms of cabinet membership, women make up only $17 \%$ of the cabinet ministers globally. The current statistics demonstrate that the higher levels of politics are extremely male dominant and women's roles are not significant.

However, why despite women facing very limited legal obstacles against their participation in different levels of political processes, still in compare with their male counterparts, women's political roles and participation are generally less significant? The following section provides an answer to this question by focusing on patriarchy as the core obstacle to women's effective political participation.

\section{Obstacles to Women's Participation in Politics}

Political participation is defined as "those legal activities by private citizens that are more or less directly aimed at influencing the selection of governmental personnel and/or the actions they take" (Verba et al., 1978). Increasing women's political participation is one of the main objectives of the gender equality chapter in the UN Sustainable Development Goals (SDGs). Sustainable Development Goal 5 clearly articulates political participation is one of dedicators for assessing gender equality (UN SDG 5, 2019). However, still the worldwide political structure stands in the women's political participation "to keep a number of mechanisms to keep women on the outside." (Deckman and Swers, 2019; 102).

Referring to Walby's argument of private and public patriarchy, politics is considered a public sphere which traditionally is not a place for women whom are expected to be a part of the private sphere namely household and family. Historically, the expansion of male dominant public can be observed "through the political structure imposed by the emerging state. State finds it convenient to use the traditional gender division of labor and resources in tribal society and places them in a hierarchical relationship both internally (husband over wife and children) and externally (lords over peasants and serfs)" (Hartmann, 1976; 145). The emphasis of the state on the superior position of men as heads of households and the inferior status of women at home resulted in "men's organizational knowledge, then, grew out of their position in the family and in the division of labor" (Hartmann, 1976; 145). The same patterns of male domination later on developed to the modern political structure.

By developing three structural categories, the following sections of this paper demonstrates how patriarchy obstructs women's participation in politics in practice:

\section{Patriarchal Structure of Politics}

It is argued that "women are seldom seen as political actors but rather as pawns to be used in the political maneuvers of men" (Collier, 1974; 89). Women are to a great extent excluded from the global political arena in compare with their male counterparts due to the patriarchal nature of politics in which "men are considered bearers of the culturally legitimated authority" (Rosaldo, 1974; 21). The male dominant model of politics is well reflected in the statistics regarding men's participation in politics. Based on statistics released by UN Women in 2019 , more than $70 \%$ of the parliament seats

1 The calculation is based on information provided by Permanent Missions to the United Nations. Some leaders hold positions of both head of government and head of state. Only elected Heads of State have been taken into account. 
INTERNATIONAL JOURNAL OF ACADEMIC RESEARCH IN BUSINESS AND SOCIAL SCIENCES Vol. 10, No. 3, March, 2020, E-ISSN: 2222-6990 @ 2020 HRMARS

around the world are occupied by men. Male ministers make up $80 \%$ of ministerial positions globally and 181 out of 193 heads of states are men. The hegemonic presence of men has developed a global political model which is male dominant, male-identified and male-centered (Chuki and Turner, 2017). Patriarchy uses "the gender role ideology as an ideological tool to place women within the private arena of home as mothers and wives" (Bari, 2005; 4). Such patriarchal model and gender role ideology can be also traced in politics through the distribution of roles among those limited number of women who have managed to be a part of the political elites. Based on the statistics published by the UN Women Report in 2019, women in ministerial positions are mainly concerned about issues including "social affairs, family, children, youth, elderly, disabled, environment, Natural Resources, Energy, Women's Affairs or Gender Equality." These issues are those women are traditionally affiliated with within a patriarchal system. On the other hand, the number of women in mostly male associated political positions such as those dealing with foreign affairs, defense, economy or justice is significantly low.

Referring back to Walby's description of private and public, women have been traditionally viewed by the patriarchy as the members of the private life and therefore a public domain like politics does not favor their presence (Ackelsberg and Shanley, 2018). For this reason, the global political structure is traditionally designed by men for men and based on the exclusion of women in different ways. One of the main avenues for patriarchy to establish its hegemony in politics is the male dominant structure of political parties even in democracies. Parties are known as the gatekeepers to parliaments and other top ranked political positions. Idealistically, "parliament is a symbol of democracy; therefore it should not disregard, limit or conduct discrimination against men and women" (Palmieri, 2011). Hence, women's representation in parliaments or cabinets is greatly tied to their representation in political parties. The resolution of the UN General Assembly 66/130 on Women and Political Participation (2012) "strongly encourage political parties to remove all barriers that directly or indirectly discriminate against the participation of women."

However, against these recommendations, women are marginalized and discriminated in political parties in many different ways such as candidates' registration requirements which normally require a hefty financial deposit that "many women are unable to fulfil due to their unequal political and socio-economic power vis-à-vis men" (OSCE ODIHR, 2014; 16). For this reason, on average, women are more likely to attribute inequality to systematic discrimination against women (Barnes and Cassese, 2017). Such discriminations have ultimately resulted in women's marginalization in decision making processes and therefore party systems in favor or men's perspective and agendas.

Nevertheless, it is important to notice that the type of party's internal structure and ideology are also important factors in determining the representation of women. The study of Golder et. al (2017) demonstrates that the number of women representatives in proportional representation party systems is more than twice of those in single-member district systems. This is argued to be the result of the centralized structure of the proportional representation parties in which party elites can increase the number of viable women candidates in response to pressure for greater representation (Tremblay, 2019). The pressure can be caused by other parties, civil society or the voters.

Another important factor to be considered about women's political participation is the political level they are being nominated for. It is assumed that women have lesser chance in occupying sates in national level politics including parliament and ministerial positions than local levels. The success of women in achieving better representation in local decision making positions may initially suggest a 
INTERNATIONAL JOURNAL OF ACADEMIC RESEARCH IN BUSINESS AND SOCIAL SCIENCES Vol. 10, No. 3, March, 2020, E-ISSN: 2222-6990 @ 2020 HRMARS

progressive trend for women's political participation yet, a closer look at the reasons indicates otherwise. It is argued that women's better representation in local politics is "because they fit easier their family responsibilities with work requirements in the local governments, and because there is less competition in local government elections" (IKNOW, 2007). Such reasons seem to further strengthen the notion of politics as a patriarchal system in which even women's progress is tied to gender role stereotypes. The patriarchal model of politics generally recognizes women's career ladder according to its established system of gender-biased division of labor. For this reason, establishing women wings or organizations has been ultimately ended up in more marginalization of women from the mainstream politics. This has also emphasized women as others who need special treatment than being integrated into the current structure of politics.

Another important obstacle to women's effective political participation is the parties' ideology. Depending on to which ideological spectrum of politics the parties belong, their behaviors towards women's representation vary. Traditionally, conservative and rightist parties are holding more patriarchal views over women and this is mostly manifested in lower number of women nominees of representation in the high-ranking levels of these parties. Recently, a religio-conservative gender climate has also emerged. This gender climate relies on the reconceptualization of family and motherhood in reference to religion, tradition and custom (Güneş-Ayat and Doğangün, 2017). In line with patriarchal values, this emerging gender climate eventually pushes women even more away from political participation.

On the other hand, leftist and liberal parties hold a more inclusive view of women as they "have long been seen as promoting women into politics, women's representation as nominees and elected officials" (Morgan and Hinojosa, 2018). On the other hand, it is also important to realize that the increasing number of female party members cannot be always translated in better representation of them in both local and national level decision making positions. A great number of parties use the 'marginal seat syndrome' to maintain their patriarchal control and the status quo while appearing gender sensitive and gender friendly. In this case, parties "field women candidates in constituencies where they are less likely to succeed" (Palmieri, 2011; 10).

However, although political parties' stance for different socio-political issues may differ from each other however in terms of gender equality, as Palmieri (2011) argues, parties "are seen as less transparent than parliaments in the sense of having institutionalized rules fair to all" (p. 75). To overcome these obstacles, parties introduced two main strategies to increase women's political participation and influence namely; "quota structure (mandated percentages of women) or target system (recommended percentages of women)" (Caul, 1999; 83). These systems and structures aim at "ensuring that women constitute at least a critical minority of 30 or 40\%" (Quota Project, 2009) in the parliaments.

Nevertheless, beside the mentioned reasons, the patriarchal structure of politics imposes itself on women willing to enter politics in several other less tangible ways including working hours which are mostly not family-friendly. This makes it particularly difficult for women who are traditionally (based on the patriarchal norms) assigned to be the primary responsible figure for family affairs to be fully engaged with their job responsibilities. Odd working hours especially at nights or the incompatibility between the working calendar of parliaments and state offices with school or public holidays usually burden women more in compare with their male counterparts. 
INTERNATIONAL JOURNAL OF ACADEMIC RESEARCH IN BUSINESS AND SOCIAL SCIENCES Vol. 10, No. 3, March, 2020, E-ISSN: 2222-6990 @ 2020 HRMARS

The patriarchal structure of politics has also created a more challenging working environment for mothers. Most governmental organizations, parliaments or state offices are poorly designed in terms of infrastructures to meet the needs of women and especially mothers with newborn babies or those mothers who breastfeed their babies. These mostly intangible and informal practices to subordinate women in politics in favor of the patriarchal status quo can be categorized as "gendered rituals in the daily operation of party bodies; super-surveillance of women's performance; gendered informal sanctions; informal networking; and uses of time" (Verge and de la Fuente, 2014). In general, the patriarchal structure of politics has made it difficult for women to make a balance between work and family.

\section{Patriarchal Socio-Economic Structure}

The current patriarchal socio-economic structure of the world is another important obstacle to women's effective political participation. Studies suggest that the "increases in education have prompted more women to enter the labor force and have improved labor market opportunities for them" (Heath and Jayachandran, 2016). The higher the rate of women's labor force outside home and the more educated they are, the more political participation from women is expected. The direct impact of socio-economic background of women on their political participation has been also emphasized in Courage Mlambo's (2019) research in which he concludes that socio-economic barriers predominantly constrain or prevent women's active political participation.

Education is one of the important pillars for patriarchy to maintain its hegemony over the social structures. In patriarchal societies, the education system mostly favors the male members of the society than the females. The current literature approves the existence of a positive correlation between women's level of education and their political participation in which "women with higher education have more interest in politics and a somewhat higher level of involvement in politics than women with less education" (Lovenduski and Hills, 2018; 110). Therefore, "in order to increase female representation, states would do well to increase education opportunities for female citizens" (Leigh, 2008; 10). This in return will help women to overcome the stereotypes on their lack of eligibility in taking over decision making positions.

During the 1970's and with the rise of social movements in the western societies, the issue of better and higher education for women became an important agenda for women's socio-economic development. The positive correlation between education and more effective participation of women in politics is reflected in Nechemias's (1987) study which indicates "for every $1 \%$ increase in the proportion of the population with a college education, the proportion of seats held by women increased by $0.5 \%$ in $1963-1964$ but by more than $1 \%$ in 1983-1984" (p.134). More recent research conducted by Simon and Palmer (2016) for the period of 1972 to 2014 validates the same correlation between education and women's political participation.

Women's participation in labor force is another important factor to be included in studying the obstacles ahead of women's political participation. The patriarchal structure of the job market has limited women's participation in several ways. Statistics demonstrate that globally only less than $30 \%$ of senior management roles are held by women (Thornton, 2019). The existence of such a gender division among the labor force has made scholars to believe that "wage labor increases the status of women, which influences women's effectiveness in garnering power in other realms of society, including politics" (Iversen and Rosenbluth, 2008; 5). Building up on this argument, the higher 
INTERNATIONAL JOURNAL OF ACADEMIC RESEARCH IN BUSINESS AND SOCIAL SCIENCES Vol. 10, No. 3, March, 2020, E-ISSN: 2222-6990 @ 2020 HRMARS

percentage of women's participation in paid labor force would then "create a group of female voters with distinct political interests especially where the rapid expansion of jobs takes place in the public sector" (Rosenbluth et al, 2006; 167).

The existence of this growing group will ultimately lead the political parties to consider them as potential voters and therefore to accommodate more of their agendas including nominating more women for legislative positions. It is also important to notice that the sexual division of labor in favor of men has prevented women's access to adequate financial resources as political campaigns are "increasingly costly and the lack of economic resources is one of the biggest obstacles to winning an electoral race" (Palmieri, 2011; 11).

The current increase in women's participation in labor force has greatly challenged the patriarchal view of the society over them. The increase in women's level of education and their greater share of job market together with rapid growth of urbanization and the decreasing fertility rates have created a situation in which women question the patriarchal traditions, values and norms. The increase in women's socio-economic level has created a pool of eligible women "to start an effective interest group demanding greater representation and influence in decision making" (Shvedova, 2005; 41).

Thus, the combination of higher education, managerial skills developed through joining the labor force and access to better financial resources would create a bigger number of eligible women to compete with men against the patriarchal political structure.

\section{Patriarchal Cultural Structure}

The patriarchal structure of culture has also significantly contributed to the marginalization of women in political activities. In societies with stronger patriarchal and traditional values, "women are not only limited by society in terms of the opportunities they seek, but also choose to limit themselves" (Inglehart and Norris, 2003; 9). This process of self-limiting and internalization of patriarchy has gone as far as many women viewing political activities as not included in their image of what a woman should do or is even capable of doing well in public (Gouws and Coetzee, 2019). The strong existence of such image has put many women in defensive position about their role as a woman in a highly patriarchal realm of politics.

Such defensive position has led women to develop a lower level of competency and self-confidence necessary for success in political participation. Thus, societies with less patriarchal structure and more egalitarian values such as the Scandinavian countries are more in favor of women's participation in politics. Statistics clearly demonstrate that "women in the Nordic countries represent, on average, over 40 per cent of their legislatures" (Palmieri, 2011; 9) while countries with stronger patriarchal social structures occupy the bottom of the list including the Middle Eastern countries. Until recently, in countries such as Saudi Arabia and Qatar, women face total exclusion from all political decision-making positions. The above examples indicate the important impact of the cultural structure of the society on women's political participation. Hughes and Paxton (2019) in their research on the progressive position of women in the Nordic countries and Merrill (2017) in his research on the low political participation of women in the Islamic societies emphasize on the crucial role of cultural values and traditions in determining the level of women's participation in politics.

In societies with stronger patriarchal structure, "traditional cultural values militate against the advancement, progress and participation of women in any political process" (Shvedova, 2005; 44). Such patriarchal traditional values have paved the way to contain women domestically and within 
INTERNATIONAL JOURNAL OF ACADEMIC RESEARCH IN BUSINESS AND SOCIAL SCIENCES Vol. 10, No. 3, March, 2020, E-ISSN: 2222-6990 @ 2020 HRMARS

the borders of the household. Traditional cultural systems usually define an ideal true woman as a woman who displays "religious piety, sexual purity, wifely submissiveness, and content with her domestic seclusion" (Jackson, 2007; 199). Such definitions and predetermined traditional roles would indeed restrict women of involving in social and political activities despite the lack of any institutional or legal barriers against their participation.

\section{Conclusion}

The principal puzzle in this paper was to investigate why despite facing very limited legal obstacles against participation in different levels of political processes, women's political roles and participation are generally less significant than their male counterparts. In search of an explanation for this puzzle, the paper explored the notion of patriarchy as the main obstacles to women's effective participation in politics.

To further investigate how in practice patriarchy can hinder women's political participation, this paper developed a structural categorization. These structural categories include the patriarchal structure of politics, patriarchal socio-economic structure and patriarchal cultural structure.

This paper demonstrated that patriarchy advocates a domesticized set of roles for women in each of these structural categories. As discussed in this paper, these roles have been achieved through developing the dichotomous discourse of public (for men) and private (for women) spheres in which women should be restricted to household. Such patriarchal views have shaped the current political, socio-economic and cultural structure in many parts of the world.

The paper has also explored the role patriarchy plays in each of these macro-level variables against women's participation in politics. The formal structure of political parties, sexual division of labor, women's lack of access to financial resources, the patriarchal system of education and traditional values and norms were discussed in this paper within the proposed structural categories.

Although many societies in the world have recognized women's political participation through different means such as the universal suffrage or abolishing discriminating legal obstacles for women to occupy political decision making however, it is the patriarchal structure of politics, socio-economy and culture which directly or indirectly restricts effective women's participation in politics. To increase women's share in political decision-making process, there is a need to challenge the existing patriarchal structure in the macro-level variables mentioned in this paper.

\section{References}

Merrill, R. C. (2017). The Middle Eastern Gender Gap: The State of Female Political Participation Before, During and After the 'Arab Spring'. In the Arab Spring, Civil Society, and Innovative Activism (pp. 121-140). Palgrave Macmillan, New York.

Ackelsberg, M. A., \& Shanley, M. L. (2018). Privacy, Publicity, and Power: A Feminist Rethinking of the Public-Private Distinction. In Revisioning the political (pp. 213-233). Routledge.

Barnes, T. D., \& Cassese, E. C. (2017). American Party Women: A Look at the Gender Gap Within Parties. Political Research Quarterly, 70(1), 127-141.

Bari, F. (2005). Women's political participation: Issues and Challenges. In United Nations Division for the Advancement of Women Expert Group Meeting: Enhancing Participation of Women in Development through an Enabling Environment for Achieving Gender.

Barrett, M. (1980). Women's Oppression Today: Problems in Marxist Feminist Analysis. 
INTERNATIONAL JOURNAL OF ACADEMIC RESEARCH IN BUSINESS AND SOCIAL SCIENCES

Vol. 10, No. 3, March, 2020, E-ISSN: 2222-6990 @ 2020 HRMARS

Beechey, V. (1979). On Patriarchy. Feminist Review, 3(1), 66-82.

Caul, M. (1999). Women's Representation in Parliament: The Role of Political Parties. Party Politics, 5(1), 79-98

Chuki, S., \& Turner, M. (2017). Women and Politics in Democratic Transitions: The Case of Bhutan. Contemporary South Asia, 25(2), 136-152.

Collier J. F. (1974). Women in Politics. In Rosaldo, M. Z., Lamphere, L., \& Bamberger, J. (Eds.). (1974). Woman, Culture, and Society. Stanford University Press.

Dahlerup, D. (2005). Increasing Women's Political Representation: New Trends in Gender Quotas. In Ballington and Karam, eds. International IDEA. 2005.

Deckman, M. M., \& Swers, M. L. (2019). Women and Politics: Paths to Power and Political Influence. Rowman \& Littlefield.

Epstein, C. F. (2007). Great divides: The cultural, cognitive, and social bases of the global subordination of women. American Sociological Review, 72(1), 1-22.

Firestone, S. (1979) The Dialectic of Sex: The Case for Feminist Revolution (first pub. 1970), London: The Women's Press.

Gerson, J. M., \& Peiss, K. (1985). Boundaries, Negotiation, Consciousness: Reconceptualizing Gender Relations. Social problems, 317-331.

Golder, S. N., Stephenson, L. B., van der Straeten, K., Blais, A., Bol, D., Harfst, P., \& Laslier, J. F. (2017). Good News: Fielding Women Candidates Doesn't Put Parties at A Disadvantage in Elections. Democratic Audit UK.

Green, Fiona, J. (2010). "Patriarchal Ideology of Motherhood". In O'Reilly, Andrea. Encyclopedia of Motherhood, Volume 1. SAGE. p. 969.

Güneş-Ayata, A., \& Doğangün, G. (2017). Gender politics of the AKP: Restoration of A ReligioConservative Gender Climate. Journal of Balkan and Near Eastern Studies, 19(6), 610-627.

Gouws, A., \& Coetzee, A. (2019) Women's Movements and Feminist Activism. Agenda, 33:2. Hartmann, H. (1979) 'Capitalism, Patriarchy and Job Segregation by Sex', in Eisenstein, Z. (ed.) Capitalist Patriarchy and the Case for Socialist Feminism, London: Monthly Press.

Heath, R., \& Jayachandran, S. (2016). The Causes and Consequences of Increased Female Education and Labor Force Participation in Developing Countries (No. w22766). National Bureau of Economic Research.

Hughes, M. M., \& Paxton, P. (2019). The Political Representation of Women over Time. In the Palgrave Handbook of Women's Political Rights (pp. 33-51). Palgrave Macmillan, London.

Hunter, D. (2007). The Obsolescent Oedipus Complex, and the Decline of Patriarchy. Journal of Sociology \& Psychology, Volume 1 (1): 17-21.

IKNOW. (2007). Women's Participation in Local Governments. The International Knowledge Network of Women in Politics.

Inglehart, R., and Norris, P. (2003). Rising Tide: Gender Equality and Cultural Change. New York: Cambridge University Press.

Iversen, T., \& Rosenbluth, F. (2008). Work and power: The connection between female labor force participation and female political representation. Annual Review of Political Science. 11, 479-495.

Jackson, R. M. (2007). Disputed Ideals: Ideologies of Domesticity and Feminist Rebellion. Working Draft. New York University 
INTERNATIONAL JOURNAL OF ACADEMIC RESEARCH IN BUSINESS AND SOCIAL SCIENCES

Vol. 10, No. 3, March, 2020, E-ISSN: 2222-6990 @ 2020 HRMARS

Johnston, R. J., Taylor, P. J., \& Watts, M. (Eds.). (1995). Geographies of global change: remapping the world in the late twentieth century. Oxford: Blackwell.

Leigh, M. (2008). Factors Affecting Female Representation in State Legis/atures. Illinois State University.

Lévi-Strauss, C. (1969). The Elementary Structures of Kinship. Beacon Press.

Lovenduski, J., \& Hills, J. (Eds.). (2018). The Politics of the Second Electorate: Women and Public Participation: Britain, USA, Canada, Australia, France, Spain, West Germany, Italy, Sweden, Finland, Eastern Europe, USSR, Japan. Routledge.

Mlambo, C., \& Kapingura, F. (2019). Factors Influencing Women Political Participation: The case of the SADC Region. Cogent Social Sciences, 5(1), 1681048.

Marx, K., \& Engels, F. (1970). Selected works in 2 volumes. Moscow: Progress.

Matland, R. E., and Donley T. S. (1996). The Contagion of Women Candidates in Single-Member District and Proportional Representation Electoral Systems: Canada and Norway. Journal of Politics 58(3), 707-34.

Millett, K. (1977). Sexual Politics. 1970. London: Virago.

Mitchell, J. (1974). Psychoanalysis and feminism. Pantheon.

Moghadam, V. M. (1992). Patriarchy and The Politics of Gender In Modernizing Societies: Iran, Pakistan and Afghanistan. International Sociology, 7(1), 35-53.

Morgan, J., \& Hinojosa, M. (2018). Women in Political Parties: Seen But not Heard. Gender and Representation in Latin America, 74-98.

Nechemias, C. (1987). Changes in the Election of Women to U.S. State Legislative Seat, Western Political Quarterly 38: 119-31.

Osce Odihr. (2014). Handbook on Promoting Women's Participation in Political Parties. OSCE Office for Democratic Institutions and Human Rights (ODIHR).

Palmieri, S. (2011). Gender-Sensitive Parliaments: A Global Review of Good Practice. Interparliamentary Union.

Pilcher, J., \& Whelehan, I. (2004). 50 Key Concepts in Gender Studies. Sage. Chicago.

Quota Project. (2009). Global Data base for Quota for Women. Available at: http://www.quotaproject.org/aboutquotas.cfm

Rich, A. (1980). Compulsory heterosexuality and lesbian existence. Signs, 631-660.

Rosenbluth, F., Salmond, R., \& Thies, M. F. (2006). Welfare works: explaining female legislative representation. Politics \& Gender, 2(02), 165-192.

Rosaldo. M. Z. (1974). Women, Culture, and Society: A Theoretical Overview. In Rosaldo, M. Z., Lamphere, L., \& Bamberger, J. (Eds.). (1974). Woman, Culture, and Society. Stanford University Press.

Shvedova, N. (2005). Obstacles to Women's Participation in Parliament. Women in parliament: Beyond Numbers, 33, 22-45.

Simon, D., \& Palmer, B. (2016). The Election of Women to the US House of Representatives: Is Demography Destiny?. In Annual Meeting of the Southern Political Science Association, San Juan, Puerto Rico, January (pp. 7-9).

Thornton, G. (2019). Women in Business: Building a Blueprint for Action. Grant Thornton International Ltd. 
INTERNATIONAL JOURNAL OF ACADEMIC RESEARCH IN BUSINESS AND SOCIAL SCIENCES

Vol. 10, No. 3, March, 2020, E-ISSN: 2222-6990 (C) 2020 HRMARS

Tremblay, M. (2019). Uncovering the Gendered Effects of Voting Systems: A Few Thoughts About Representation of Women and of LGBT People. In Gender Innovation in Political Science (pp. 91-114). Palgrave Macmillan, Cham.

United Nations. (2019). Sustainable Development Goal 5. United Nations SDGs Knowledge Platform. Available at: https://www.unwomen.org/en/digitallibrary/publications/2019/09/progress-on-the-sustainable-development-goals-thegender-snapshot-2019

United Nations. (2005). Women and Elections. United Nations Department of Public Information. Available at:

https://www.un.org/womenwatch/osagi/wps/publication/WomenAndElections.pdf

United Nations Women. (2019). Women in Politics: 2019. Available at: https://www.unwomen.org//media/headquarters/attachments/sections/library/publicati ons/2019/women-in-politics-2019-map-en.pdf?la=en\&vs=3303

Verba, S., Nie, N., and Kim, J. O. (1978). Participation and Political Equality: A Seven-Nation Comparison. New York: Cambridge University Press.

Verge, T., \& de la Fuente, M. (2014). Playing With Different Cards: Party Politics, Gender Quotas and Women's Empowerment. International Political Science Review, 35(1), 67-79.

Walby, S. (1989). Theorising Patriarchy. Sociology, 23(2), 213-234. 